\title{
FOREST POLICY AND LEGAL PLURALISM: A CASE STUDY IN LUWU DISTRICT, INDONESIA
}

\author{
Lukas Rumboko Wibowo ${ }^{1}$, C. Woro Murdiati. $\mathbf{R}^{2}$ \\ \& Digby Race ${ }^{3}$, Yustina Ambarini Murdiningrum ${ }^{4}$
}

\begin{abstract}
This paper investigates how the potential of the newly enacted village forest policy to improve the welfare of local people and examines how different actors at local level perceive a legal framework suitable for improving the welfare of local people and enhancing local development. We conducted research through in-dept interviews involiving 75 respondents from different actors, such as policy makers, politician, village chief, customary chief and villagers. The research establish that forest policy on village forestry was a good option for local people to improve their welfare; however, litle understanding of the substance of the newly village forest policy of local development actors due to limited public consultation undertaken at district and village level would become a real challenges for executing the policy. The work of the policy is also depend on the extent to which the central goverment is capable of undertanding local context where multiple legal system operates.
\end{abstract}

Keywords: Forest policy, legal pluralism, customary forestry, village forestry, and local welfare

\section{Introduction}

The existence of Perdas and orders have give possibility to support development of village forest area, especially on Sepakat and Lantang Tallang. To makes the law exist, the customary community should still have a role, indeed as main player. In aimed to fulfil the needed of law of village forest area, the legal frameworks must avoid complicated and bureaucratic regulations.

\section{Village forest policy}

${ }^{1}$ Junior Research scientist at Forest Research Development Agency (FORDA). Bogor. Indonesia (email: Lukas_19672000@yahoo.com and lwibowo@csu.edu.au). Obtained Bachelor of Sociology (Drs) from University of Gadjah Mada (1992), Master of Science of Tourism and Environments from University of Wageningen University, the Netherlands (2002), and a Doctor of Philosophy (PhD) from University of Charles Sturt, Australia (2012)

${ }^{2}$ Senior Lecturer of Adat Law, Faculty of Law, University of Atmajaya Yogyakarta (email: worofh@ yahoo.com). Obtained Bachelor of Law (S.H.) from University of Atmajaya, Yogyakarta, Master of Law from University of Gadjah Mada (1999) and a Doctor of Philosophy from University of Gadjah Mada (2012)

${ }^{3}$ Senior Research Scientist at Charles Sturt University. Obtained Bachelor of Applied Science - Environmental Horticulture from University of, Melbourne (1984). Graduate Diploma of Environmental Management from University of La Trobe (1994), Master of Applied Science from University of Charles Sturt (1996), and a Doctor of Philosophy from University of the Australian National (2000)

${ }^{4}$ Volunteer Junior Research scientist at Palma Foundation. Obtained Bachelor of Law (S.H.) from University of Gadjah Mada (1997). Master of International Development Studies from University of Wageningen, the Netherlands (2007) and a PhD student at University of Charles Sturt, Australia (20092013) 
The Ministry of Forestry $(M o F)$ on Monday 30 ${ }^{\text {th }}$ March 2009, officially inaugurated the Lubuk Beringin Village, Bungo District, Jambi Province as a village forest. The inauguration is mandated by the Government Regulation No. 49/Menhut-II/2008. The Village Forest is developed under the umbrella of Community Based Forest Management (CBFM). The objectives of the policy are:

1. providing a legal right to manage production forest for a particular village community that is located in and surrounding forest area;

2. providing a better access to the rural community;

3. supporting rural livelihood system and rural development; and

4. improving rural governance in managing forest resource.

While based on a survey conducted by the department of forestry and Connecticut show that there are more than 1,000 villages located in the woods and around 8,000 villages located on the outskirts of the forest. Specifically, in Luwu Utara District there were 100 villages classified as undeveloped.In this paper/research, we focused to Sepakat and Lantang Talang villages. Sepakat village was classified as a much undeveloped village and Lantang Tallang was categorised as undeveloped village and they are also located nearby to the forest.

Figure 1 The number of villages based on the location

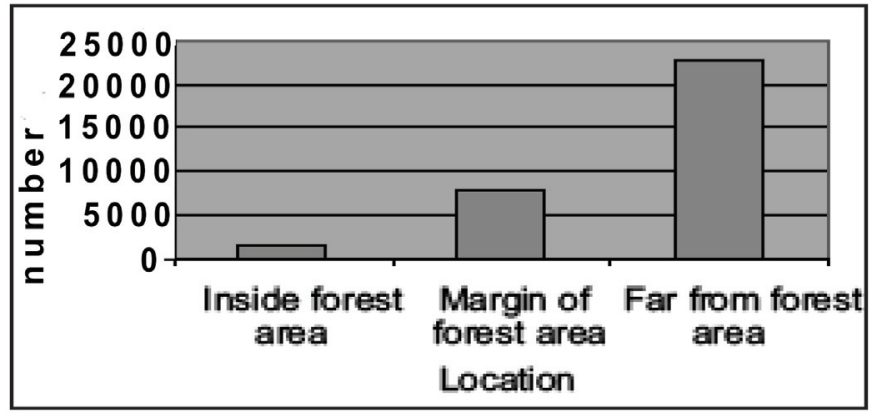

Source: Dephut-BPS, 2007.

Figure 1 refers to the survey conducted in 15 provinces; the total number of villages was 31,957 villages comprising 1,305 villages located inside the forest area, 7,943 villages located in the margin of the forest area, and 22, 709 located outside the forest area. ${ }^{5}$

This policy seems to be one alternative solution to reducing rural poverty the community forest is estimated at more than 10 million people and strengthen forest governance at the local level. This paper tries to study the potential of the newly enacted village forestry to improve the welfare of local people and explore legal framework settings from different actors perspectives in order make the policy work in the mids of co-existance among multiple-legal order at local level.

${ }^{5}$ The Ministry of Forestry and Statistical Bureau. 2007. Identificationof villages in the foreststated land. Dephutand BPS. Jakarta. 


\section{Legal pluralism as constraining or enabling condition for local people}

International contact within globalization and free trade has encouraged economic, financial, political and law transactions. This is occurred in bilaterally or multilaterally context. In addition, the development of information technology followed by disseminating universal ideas has resulted in international, national, and local laws more freely to cross over the boundaries of the countries and social arena at different layers. Consequently, different laws, such as international, national, religious, customary laws will do interaction each other. It means they will compete, contested or strengthen each other. ${ }^{6}$ The new formation of legal interaction have changed the character of those of laws. However, since law is usually subordinated under economic, financial, and technology as well as culture. This situation results in creating problems. The essential legitimizing function of law in social, economic and political organization would be ignored by reducing 'the legal' dimension to the 'economic' or 'political' spheres.

In forest management practices, there are various rules that apply and live and interact among them, such as laws of the State, customary law, religious law, or rule of law project and made at the district level. Individual person would probably choose one of the rules as a basis for claiming on a particular resource. Legal pluralism on the other hand can create uncertainty, especially when there is a conflict because someone may not know the types of law or regulation that may be relevant. But at the same time multiple legal frameworks will provide flexibility for people to maneuvers in the utilization of forest resources. ${ }^{8}$ Legal pluralism is defined as the possibility of existence of more than one legal system in society. ${ }^{9}$ As a result, in this context interaction and hybridization between different legal systems is often unpredictable. Therefore, legal anthropologists and some social scientists generally use broadly for various of types of normative ordering in society, not limited to state law, but also customary law, religious law, and projects law, such as the village forest policy. ${ }^{10}$

\section{A. State Law}

Legal pluralism as a concept and academic study has evolved to this day. In the history of its development and then came the demand that academic discourse can address the practical needs, especially in answering fairness problems faced by vulnerable groups in society. This approach reveals the fact that legal pluralism in social reality, the State law is not the only law that monopoly behaviour of citizens. ${ }^{11}$ State law but in reality is often too dominant. Applicability of forestry law (No.41/1999) is often considered the parties are actively fighting for the rights of indigenous peoples as a barrier for indigenous peoples to fight for their rights in managing the forest, like the case of indigenous

\footnotetext{
${ }^{6}$ Irianto, 2006

${ }^{7}$ Von Benda Beckman, F., Keebet von Benda Beckman, Anne Grifiths. 2005. Mobile people, mobile law: Expanding legal relations in a contracting world. Ashgate Publishing.

${ }^{8}$ Irianto, 2006.

${ }^{9}$ Roth, D, "Ambition, Regulation and Reality: Complex use of land and water resources in Luwu, South Sulawesi, Indonesia,"(Dissertation of Wageningen University. The Netherlands, 2003).

${ }^{10}$ see F. von Benda-Beckmann, 1997, 2001, 2002 in Roth, 2003Von Benda Beckman, F., Keebet von Benda Beckman, Anne Grifiths. 2005. Mobile people, mobile law: Expanding legal relations in a contracting world. Ashgate Publishing.

${ }^{11}$ Irianto, 2006
} 
forests Kasepuhan Citorekin Banten. ${ }^{12}$ In addition the regulations relating to license the production of forest management is considered to have exacerbated and limited customary communities and others in gaining access in forest management. ${ }^{13}$ In this context, the law functions as constraining rather than enabling condition for customary people. Thus, eexisting legislation often limits forestry activities, such as hunting, collecting fuel wood that millions of poor rural people depend on. ${ }^{14}$ While from the perspective of the State of law rule will provide a strong legal basis for the existence of indigenous peoples.

\section{B. District law}

Many countries have adopted deregulations programs since the late 1980s, today usually referred to as better regulation. ${ }^{15}$ However, in some countries, such as in Indonesia in response the political changes following the decentralisation system, the district governments issued many regulations which aims to generate more district income. For instance. ${ }^{16}$ Ngakan reported that by December 2001 the Luwu Utara District Government issued 89 district regulations (Perda) and most of which governed new local taxes and business permits. There is no Perda that promote and discuss the sustainable forest management. This reflected that the District focused on economic paradigm emphasising on district own-source revenue $(P A D)$. In addition, Potter (2008) claimed that the majority of district governments use the opportunity of Law 22/1999 for emerging rent seeking behavior of local bureaucrats and politicians. ${ }^{17}$

\section{Customary Law}

During the colonial system, the Dutch government perceived the customary law at the lower rank of the Dutch Law. It was recognised by the Dutch. The existence of the agrarian law (agrarische wet 1870) through Staadblad 1870-55 asserted that the Dutch was not allowed to reduce the rights of the customary people over their land except through expropriation and by the law. ${ }^{18}$ After Indonesia independence declaration in 1945, Indonesia issued the national constitution (UUD 1945). The national constitution stated that all of state bodies and regulations still operated, as long as it has not regulated yet new (regulation) based on this act. Following the national constitution, the Ministry of Forestry issued the basic forestry law (UU No.5/1967 amended into UU No.41/1999). Consequently, they should struggle for getting legal recognition if they (customary communities) will get legal access to manage their forest.

${ }^{12}$ Sandra Moniaga. "Pluralisme Hukum Negara dan Ketidakpastian Hak Masyarakat Adat" Forum Keadilan. (01 Oktober 2006)

${ }^{13}$ Kaimowitz, 2003

${ }^{14}$ Kaimowitz, 2003

${ }^{15}$ Van schooten, H., \& Vershuuren, J. 2008.Introduction and conclusions (unformatted and unedited preprint version) from the book: International Governance and Law: State Regulation and Non-State Law. Edited book. Edward Elgar Publishing, Cheltenham. Tilburg University, the Netherlands.

${ }^{16}$ Ngakan, P.O., Ahmad, A., Wiliam, D., Lahae, K., \& Tako, A. "The Dynamics of Decentralization in the Forestry Sector in South Sulawesi: The History, Realities and Challenges of Decentralized Governance", (Research of Hasanudin University and CIFOR Bogor. Indonesia, 2005)

${ }^{17}$ LesleyPoter. "Dayak Resistance to Oil palm Plantations in West Kalimantan, Indonesia," This paper was presented to the $17^{\text {th }}$ Biennial Conference of the Asian Studies Association of Australia in Melbourne 1-3 July 2008.

2006)

${ }^{18}$ Susilaningtias. "Potret Hukum Adat Pada Masa Kolonia", Forum Keadilan No. 23. (01 Oktober 
In practice, institutionally, they persist, co-exist and interact uneasily with statesponsored governance institutions whose mandate to implement and enforce state-sponsored law. ${ }^{19}$

In some extents, even though customary law tends to be marginalised by state law, it can be viewed as non-state law which is perceived by some policy analysts as an alternative to state law. Furthermore, to mitigating the limitations of state law, non-state law could be a better alterative solution for resolving the development problems, such as globalization, since non-state law is not necessarily restricted by national borders. ${ }^{20}$

\section{Project Law}

The Ministry of Forestry $(M o F)$ on Monday $30^{\text {th }}$ March 2009, officially inaugurated the Lubuk Beringin Village, Bungo District, Jambi Province as a village forest. The inauguration is mandated by the Government Regulation No. 49/Menhut-II/2008. The policy was issued to enable local people to improve their well-being. This law was expected to enhance participation of local people in managing forest resource. However, we perceive that a policy and program such as a village forest can be called a state order, as it was issued by the government -- in Indonesia village forest policy have been practiced for more than a hundred years. In technical terms, 'village forest' is forest areas that administratively come under particular village governance and are managed by rural communities. In the past before independence, some parts of Central Java and East Java have recognised village land assets in the form of rice fields, dry land and forest. The village forest assets are called "wewengkon". This term refers to a certain authority to manage and utilise forest resources for the sake of the local people. ${ }^{21}$

Figure 2-Coexisting Multiple Legal Orders modified from Meinzen-Dick \&Pradhan (2002)

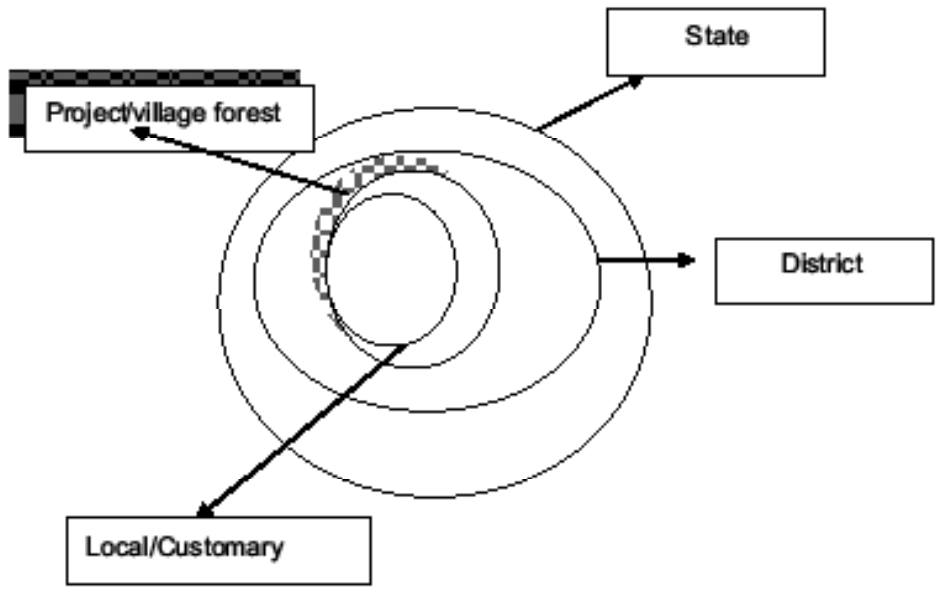

\footnotetext{
${ }^{19}$ Benyamin, 2006

${ }^{20}$ Bastmeijer and Verschuuren 2005, p. 317 cited in Schooten\& Van verschuuren, 2008

${ }^{21}$ SIKLUS. Hutan Desa: Menemukan Kembali Peran yang Hilang. SIKLUS Edisi Khusus Februari 2003.
} 
In brief, Meinzen-Dick \&Pradhan (2002) stated that in most areas of social life and in most social-political settings operates various forms of legal systems which are contextual to the society life. It is believed that in each social life, it can produce and enforce rules or normative and cognitive repertoires. Therefore different laws can coexist in the same place, such as:

1. State (or statutory) law made by legislatures and enforced by the government;

2. District law, such as regional regulation (Perda), Bupati's decision, district regulation concerning village governance;

3. Customary law, which may be formal written custom or living interpretations of custom;

4. Project (or donor) law, including regulations associated with particular projects or programs, such as an village forest;

5. Organizational law, such as rules developed by user groups; and

6. A range of local norms, such as prohibition to cut trees along side the river banks, which may incorporate elements of other laws.

The coexistence and interaction of multiple legal systems within domain of a social setting and social life is called legal pluralism. This situation often causes overlap between them as portrayed in Figure 2.

The coexistence of various laws in one space often produces domination among them. It means all laws are not equal, or equally powerful. In some cases state law has a dominant role and more powerful than the other laws. In addition, through the state law, outsiders can use the law to claim resources from local people, even though the local people usually had had local law. For instance, in Indonesia after the end of the Soeharto regime, there were many changes in laws and regulations, including the Basic Forestry Law (from UU No6/1967 into UU $41 / 1999$ ), which provide any private sectors to reclaim communal lands own by customary communities since state law just recognised formal evidence, such as land certificate to prove the ownership system. However, the state law is only as strong as the bureaucracy that stands behind them. ${ }^{22}$

\section{Methodology}

In this research we used the qualitative method using a case study. ${ }^{23}$ The research used an open-ended questionnaire and we interviewed some relevant key informants and other related stakeholders at different levels, such as at the provincial level, district and local level. We conducted in-depth interviews with key informants. It was about 50 key informants embraced in an extensive interviews. They were policy makers at the district, chief of customary communities, head of village, local businessman, NGO activist, migrants, and farmers. The interviews took around 2-3 hours for each interviewee.. For selecting respondents we used purposive method. The research also applied the observation method for supporting the data. We also collected some relevant law and regulation documents both at national and district, as well as local

${ }^{22}$ Meinzen-Dick, R. S., \& Pradahan, R. 2002. Legal Pluralism and Dynamic Property Rights. CAPRi WORKING PAPER NO. 22 CGIAR Systemwide Program on Collective Action and Property Rights. International Food Policy Research Institute 2033 K Street, N.W. Washington, D.C. 20006 U.S.A.

${ }^{23}$ Yin, 1994 
levels. Finally, we also collected some secondary data from relevant information. The fieldwork was undertaken from March until June 2007. We conducted the research with the assistance of a local resident in the Luwu Utara District. My local assistant had visited the study area many times for research in collaboration with the Centre for International Forestry Research (CIFOR) and the University of Hassanudin, South Sulawesi. We then used a legal interpretative approach supported by relevant secondary data found in the study area.

\section{Results and discussion}

We would like to demonstrate this problem using a case study that we carried out in 2007. This case study was focused on examining the potential of the newly enacted village forestry to improve the welfare of local people and exploring legal framework settings from different actors' perspectives in order make the policy work in the mids of co-existance among multiple-legal order at local level. Before answering the two main research question, we would like to discuss briefly the context of the study area.

Map 1 The research site based on the consensual forest land use 2005-2014

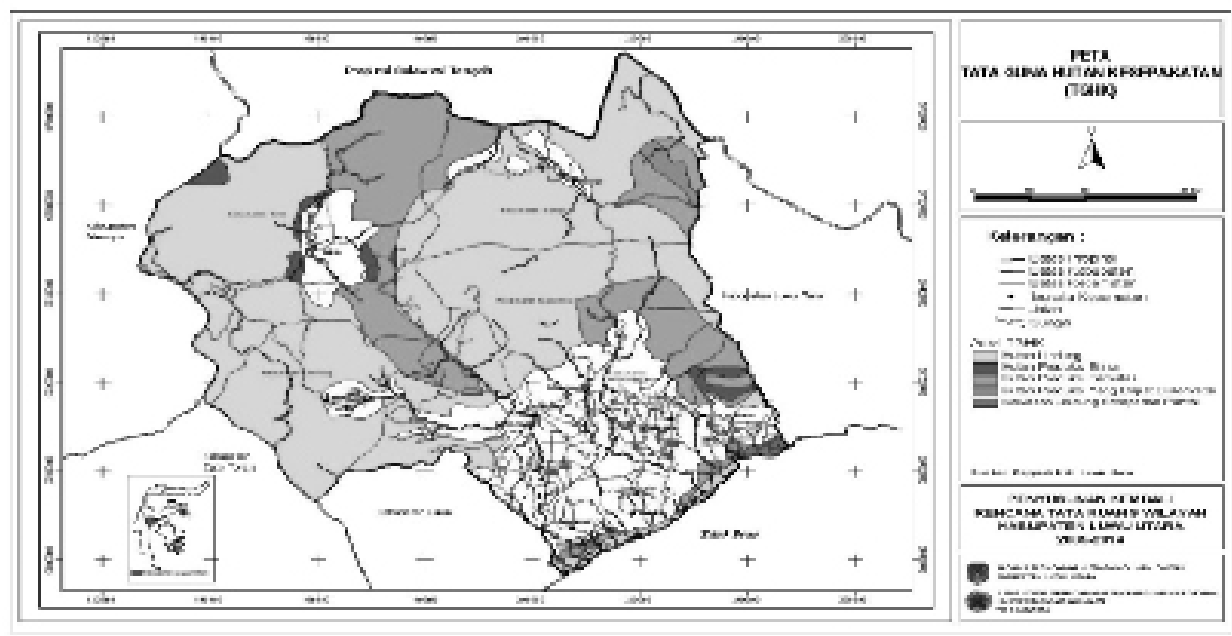

The research fieldwork was conducted in the Luwu Utara District, focusing on the case study samples at Sepakat and Lanttang Tallang village as described in Map 1. The Sepakat village is located on the boundary with the state forest under jurisdiction of Patikala watershed and is a part of the Balise watershed sub-region. Patikala is about 33,829 hectares and comprises 20,651 hectares of protected forest (Hutan Lindung/HL), 11,547 hectares limited production forest (Hutan Produksi Terbatas/HPT), and areas for other purposes (Areal Penggunaan Lain/APL) of about 1,631 hectares. The production forest and APL is the log over area of PT Panply. The local communities can use forest products, such as rattan and honey in all Patikala watershed regions, while logging is only permitted in the APL. The Sepakat and the Lantang Tallang village are located near the production forest which was formerly managed by PT INCO forest 
concessionaire. ${ }^{24}$ The population of the Sepakat Village was 1,179 people with density around 13 people per $\mathrm{km} 2$. The total number of households (Kepala Keluarga) was 219. Lantang Tallang Village was comprised of 711 households with density of three people per $\mathrm{km} 2 .^{25}$

\section{Legal complexity and problems of resource exploitation}

Luwu is a fascinating place for research into legal anthropology regarding the use of natural resources, since the district experienced some remarkably changes. Firstly, the increasing use of natural resources in tandem with increasing population has triggered increasing management problems. Secondly, the dynamic changing of resource and population need reframing and redistributing rights to resources, changing existing practices of use and management, increasing state control over resources and people and supporting efficient property mechanisms for resources in order to achieve goals of such state development programs. ${ }^{26}$ In addition, having separated away from Luwu District in 2001, the Luwu Utara District Government has faced many problems, especially during three years of implementing decentralization. The inconsistency of national laws and regulations is one main obstacles faced by the district. ${ }^{27}$

In fact, even today, this is generally seen as one of the major weaknesses of the legislature. There are too many laws operate, and sometimes contradicting each other, or incompatible. ${ }^{28}$ As a result, the existence of legal complexity that operates in heterogeneous arenas of forest extraction such as in Luwu results in a potentially high degree of legal, livelihood, and social instability. ${ }^{29}$ Therefore, in the post colonial era Indonesia is characterized by legal complexity ${ }^{30}$, so legal complexity also has a crucial role in producing problems of resource exploitation in $L u w u^{31}$

Luwu Utara is a new district created in 2001. In 2003 most of its eastern area was separated off to install yet another new district, Luwu Timur (or East Luwu). Until the middle of 2004, the government affairs of both districts continued to be managed jointly. The Luwu Utara consists of 19 sub districts (kecamatan) with 271 villages. The total population is around 452 498, with a 2.47 per cent growth rate (BPS Kabupaten Luwu Utara, 2002).

Up to 1997, seven large scale forest concessions (Hak Pengusahaan Hutan, $\mathrm{HPH}$ ) operated in the district with concessions comprising 354, 525 hectares. However, by 2001, only one HPH - PT. Panply - was still operating, and in mid 2002 it stopped its operations. In 2003 a forest concession (PT Matano) started operating in the area and the HPH also bought logs from privately owned land. Research findings showed that there were four main factors behind the HPH companies ceasing operations. First, valuable timber stocks in the forests of Luwu Utara had declined steeply. Second, the number of claims and complaints from the local communities over their concession areas were increasing,

\footnotetext{
${ }^{24}$ Ngakan, P.O., Ahmad, A., Wiliam, D., Lahae, K., \& Tako, A, op. cit

${ }^{25}$ BPS KabupatenLuwu Utara, 2002

${ }^{26}$ Roth, D. op. cit

${ }^{27}$ Ngakan, P.O., Ahmad, A., Wiliam, D., Lahae, K., \& Tako, A, op. cit

${ }^{28}$ Wiener, 2006 in Schooten\&Verschuuren, 2008

${ }^{29}$ Roth, D, op. cit

${ }^{30}$ F. and K. von Benda-Beckmann, 1999; Lindsey, 1999a in Roth, 2003

${ }^{31}$ Roth, op. cit
} 
especially after the reform era. Third, local taxes and levies were increased after decentralization. Fourth, the district government made policy disincentives since the district had more power after decentralization. ${ }^{32}$

Refer to the participatory mapping done, with a particular NGOs, the To'makaka Masapi claimed around 232 hectares. These areas are derived from the government map of Luwu Utara District; the claimed land was classified by the state as a non-forestry utilization area (Areal Penggunaan Lain (APL). However, based on AMAN (2007) historically, the total area of Masapi customary people covered around 26,000 hectares and 17,000 hectares of that were classified as forest land. The local community claimed in interviews around 12,000 hectares both in production and protected forest. Specifically for Lantang Tallang village, the local community claimed 100 hectares as communal land and in Sepakat around 50 hectares. ${ }^{33}$

After the Soeharto regime, the Luwu Utara District issued some regulations that focused on increasing regional income $(P A D)$. For instance, the District passed the district regulation (Perda No.7/2002) that governs conservation of forest resources. This Perda was meant to support forest resources at the local level. ${ }^{34}$ Short term economic interests improve PAD became main priority during the initial stage of decentralisation. Conservation initiatives and local social or economic development opportunities were ignored. ${ }^{35}$ In addition, under District Regulation No. 5/2001 concerning permits to utilize forest resources, Luwu Utara District Government issued 13 out of the 41 permit applications proposed by cooperatives or the private sector. These 13 permits consisted of 10 Rattan Collection Permits, 2 permits for harvesting timber on privately owned land (IPKTM) and 1 permit for utilization timber for road construction (IPKPJ). In addition, the district was still reviewing other permit applications and waiting on approval for more from the Minister of Forestry and Estate Crops. Most of the applications submitted for central government approval were from companies seeking for commercial licenses for plantations. ${ }^{36}$

However, after decentralisation at least 11 District Regulations were issued in the Luwu Utara District concerning village forests, nine of which were strongly connected with village governance. ${ }^{37}$ However, these regulations are not well-understood by the national and local leaders and have not been integrated into village forest policy but at this time there is a proposal for the establishment of village forests in the area. The reason is that at the local level today many customary people in isolated areas are still living in, and they are also still dependent on forest resource as source of livelihood system. ${ }^{38}$ Likewise, the populations that live in the Sepakat and Lantang Tallang Villages are indigenous people or customary people. In fact, in the research area the local community which is a part of the Masapi customary people have developed their own local rule which govern forest governance at the local level. ${ }^{39}$ Ngakan stated: "A customary, or Adat, community is a group with a collective right over a certain

\footnotetext{
${ }^{32}$ Ngakan, P.O., Ahmad, A., Wiliam, D., Lahae, K., \& Tako, A, op. cit

${ }^{33}$ Ngakan, op, cit

${ }^{34}$ Ibid.

${ }^{35}$ Yasmi et al., 2005

${ }^{36}$ Ngakan, op, cit

${ }^{37}$ See Appendix 1

${ }^{38}$ Bachriadi \& Sardjono, 2005

${ }^{39}$ Wibowo, forthcoming
} 
area, established by their genealogic and territorial history. This collective right came about naturally, at the time the customary community was established, hence the existence of a collective right depends wholly on the existence of the community itself".

In the case of the Sepakat and Lantang Tallang villages, there is unwritten law that relates to the use of forest resource. The customary law also governs the interaction between members of rural communities. In forest resource governance, they have developed some local knowledge systems, including sanctions. This system forbids the member of customary groups to cut down under $20 \mathrm{~cm}$ diameter trees. If anyone breaks the law they will receive punishment from the chief of the customary group called Tomakaka. Tomakaka is the local name of the customary chief. Another rule forbids member of communities to collect some fruits from the forest before they ripen. Also, the local people cannot encroach on very steep or protected areas. Consequently, ${ }^{40}$ stated that the task of community members was to conserve the forest, and maintaining its value for future generations. Anyone who broke this principle could be punished in line with the customary rules.

\section{Supportive laws and village forest}

In the light of laws and regulations, many laws and regulations coexist and operate in the area and legally the situation of these villages is complex. The laws and regulations that relate to village forest governance are: Law No. 5/1990 re natural resource conservation and its ecosystems; Law No. 23/1997 re principles for environmental management; Law No. 41/1999 re forestry and Law No. 32/2004 re regional government; Government Regulation No. 49/ Menhut-II/2008 re the village forest; Government Regulation (PP No.6/2007) $r e$ forest arrangement, management planning and utilisation; and Government Regulation No 72/2007 re village governance. The following Perdas support the establishment of the village forest:

\section{A. District Regulation No. 6 /2007 concerning Village Consensus Board (BPD)}

In line with the implementation of the government regulation No. 72/2005 article 42 concerning village, the members of $B P D$ consists of key persons in a certain community, religious leaders, youth leaders, womens' leaders, the chiefs of customary people and others, and they are to be elected based on community consensus. The existence of the $B P D$ is crucial since in collaboration with the village chief it will make a certain village regulation. Therefore, the village forest policy needs a certain village regulation in order to be operational. The formation of a management institution for village forest policy, such as a customary institution, Village Forest Corporation (BUMD) or cooperative must be established by village forest policy.

\section{B. District Regulation No. 7/2007 concerning village governance}

In line with the implementation of the regulation, village governance means the activity that is run by BPD and village institutions. The existence of this rule can support good governance and provide the possibility of checks and balances.

${ }^{40}$ Ngakan, op, cit 
These principles will support village forest policy in meeting its objectives, such as sustainability, democratisation and transparency, participatory and social welfare.

\section{District Regulation No. 9 /2007 concerning village budget}

Articles 17 and 18 regarding the formation of a village forest corporation $(B U M D)$ in accordance with village potential and needs state that the establishment of the BUMD must be stipulated by village regulation. Article 17 gives the reason that it will enable a village to run and finance the project more easily. Article 18 asserts that the rule, organisation, rights and responsibilities, benefit sharing and partnership with third parties will be further affected by the Bupati decision. Therefore, if the Sepakat and Lantang Tallang village is inaugurated as a village forest and a $B U M D$ is appointed as the management institution, they must await the Bupati decision about $B U M D$ regulation.

\section{District Regulation No. 10/2007 concerning village collaboration.}

In line with the implementation of article 85 , government regulation (PP No. 72/2005) district regulations are needed that require village collaboration. Article 2 passage (2) (Perda No 10/2007) mandates that a village be allowed to enter partnerships with third parties; the decision must be made in collaboration with the BPD and then must be reported to the Head of Regional Government through the Chief of Sub District.

The objectives of collaboration or partnership are (article 4):

1. Giving legal certainty and security through written rule being endorsed collectively.

2. Providing equal and rational advantage and benefit for both sides.

3. Increasing productivity and the role of the village as prime mover of development.

4. Optimising the potential of village resources for enhancing local community welfare. In addition, article 7 mentioned that villages can collaborate in the use of forest resources and the application of relevant technology by promoting environmental sustainability.

The existence of this rule explicitly allows Sepakat and Lantang Tallang village to make a partnership in managing its forest. It also tries to protect the village by implementing collaboration, so any partnership will not have a negative impact on the village.

\section{E. District Regulation No. 12 / 2007 concerning village regulation}

The village as the rightful conductor of village forest management must make village regulations that contain some principles of sustainable forest management. Rural institutions can initiate village regulations. The initiative can also come from a BPD or a member of a rural community. The existence of village regulations will make the village forest management more democratic if they are made democratically. 


\section{F. District Regulation No. 13/2007 concerning the delegation of district authority to village level}

This regulation provides opportunity for villages in the Luwu District to receive a right to manage village forest. In article 3 , it is asserted that district authority over a particular governance business can be delegated to the village, especially governance business that can directly increase community services and empowerment. In article 2 it is mentioned that the delegation of authority must be accompanied by financial assistance which comes from district budgeting.

Article 5 mentioned that some authorities from the district level can be delegated to the village level, such as estate crop and forestry sector, village autonomy, community empowerment, and environmental sector. ${ }^{41}$

\section{G. District Regulation No. 15/2007 concerning village development planning}

In article 2 of this law, it is stated that rural development planning must be managed as an integral part of the district development system, using a participatory approach that involves village community institutions. This rule creates the possibility for members of rural communities and other related stakeholders to propose a village forest as part of rural development planning. This opportunity is a way to support community empowerment at the rural level.

\section{The potential of the newly enacted village forestry to improve the welfare of local people}

There are various village assets in the form of forests. ${ }^{42}$ These assets have the potential to be the main basis of the village economy if they are managed properly. The research shows that in Sepakat Village, 71 per cent of total income derives from collecting forest products, 7 per cent from horticulture or agriculture, 7 per cent from skilled labor, 7 per cent from trading, 4 per cent from farm labour, and 4 per cent from other sources. Similarly, in Lantang Tallang Village, 60 per cent comes from collecting forest products, 20 per cent from garden, 13 per cent from trading and 7 per cent from skilled labour.

Learning from the forest utilisation conducted by a private sector who has been working in the area, one permit of about 500 hectares for utilising rattan in the state forest land can absorb 200-300 labour force and six people who work in a warehouse. Therefore, the stipulation of the village forest policy will absorb more labour and cause more benefit to the local people. Regarding the labour force, the number of workers in the Sepakat Village was 900 people.

The village forest policy would improve the well-being of the local people if the policy: (a) involve communities more closely in development planning; (b) improving community services and equitable distribution of development; (c) creating financial efficiency for development according to local needs; (d) improving welfare through the village apparatus; (e) activate local economies to support the livelihood of rural people; (f) promoting mutual trust, a sense of responsibility and providing challenges to revive village potency and

\footnotetext{
${ }^{41}$ See in Appendix 4

${ }^{42}$ See Appendix 2
} 
initiative; (g) improve village capacity for managing development and good governance mechanisms; (h) opening an arena for valuable learning regarding rural governance, communities and consensus boards (BPD); and (i) stimulating the emergence of local participation. ${ }^{43}$ However, the distribution of roles and responsibilities is dependent on the agreement of all stakeholders and in different locations and social-political settings might vary. ${ }^{44}$

\section{Challenges for improving local welfare}

The statistical office of the Luwu District (2002) reported that more than 31 per cent of the total population of the Luwu Utara still live under poverty line, most of whom are living in forest areas. For instance in the Sepakat and Lantang Tallang village 90 per cent of the population depend on forest products, especially rattan. The farmers who collect rattan often have to deal with erratic price movements. When they sell their products, they must receive the cheapest price as determined by local traders. They have no bargaining power against the local traders. Consequently, it is not surprisingly that there were 100 villages classified as undeveloped in Luwu Utara District. Sepakat village was classified as a very undeveloped village and Lantang Tallang was categorised as an undeveloped village. The introduction of village forest policy will improve the welfare of local people and help their villages improve through a better income from the forest.

Problem relating to local rule ${ }^{45}$, claimed that today, the To'makaka Masapi (customary institution) has no key role, power, or authority in regulating the use of the forests in this area (Sepakat village), even in daily practice. It has happened since economic pressure and market demand drive this condition, for instance consumptive behavior is a new mode of behavior for some local people. Interviews showed that some people become less committed to protect forests. They often engage in collaboration with migrants from other districts (usually Buginese) to log forests and claim the land. They sell the land to buy consumer goods such as VCD players, televisions, motorbikes, cars etc. ${ }^{46}$

Generally, Eko \& Rozaki, (2005) mentioned that there are some weaknesses in the rural sector, especially village capacity for managing governance institutions: 1) weak internal consolidation; 2) weak responsibility and village apparatus competency; 3) powerful and dominant chief of rural governance; 4) lack of understanding of modern administrative frameworks; 5) lack of capacity in managing rural finance; 6) lack of capacity in leveraging local potency; 7) weak response of rural governance to the rural communities needs; 8) lack of capacity in making good village regulations; 9) lack of capacity in creating innovation in terms of governance, service and village development; 10) weak rural communities' participation. Some problems mentioned earlier are responsibilities of all stakeholders. Therefore village autonomy in managing forests would be successful if these problems were resolved. ${ }^{47}$

\footnotetext{
${ }^{43}$ Eko, S, \& Rozaki, A.(2005). Prakarsa Desentralisasi dan Otonomi Desa. IRE PRESS: Jogjakarta

${ }^{44}$ See Appendix 5

${ }^{45}$ Ngakan, op, cit

${ }^{46}$ Ngakan, op, cit

${ }^{47}$ Eko\&Rozaki, op. cit
} 


\section{$X$. Exploring legal framework settings from different actors perspectives}

Table 1 shows that generally most of respondents responded the village forest policy positively. They were expecting the policy would be exercised in the area, so that they can improve their well-being. However, they also provided negative comments since the policy has not yet promoted and consulted to them. Theye were expecting that in order to make the policy work, the central and district governments should not develop laws and regulations which local people will find difficult to implement, such as high taxes and levies, or a rigid work plan. One principle in making a formal legal framework should be to enable village forest policy to develop according to the local people's needs and aspirations. The legal framework should be made so as to provide an incentive for local people.

Table 1 Village forest policy from different perspectives

\begin{tabular}{|c|c|c|}
\hline Actors & Positive perception & Negative perception \\
\hline Politician & $\begin{array}{l}\text { Good policy and politically we } \\
\text { will support it }\end{array}$ & $\begin{array}{l}\text { We do not the real } \\
\text { substance of the policy }\end{array}$ \\
\hline $\begin{array}{l}\text { Provincial and } \\
\text { District policy } \\
\text { makers }\end{array}$ & $\begin{array}{l}\text { An alternative for improving the } \\
\text { well-being of villagers and we } \\
\text { will support it. }\end{array}$ & $\begin{array}{l}\text { Limited promotion and } \\
\text { public cosultation }\end{array}$ \\
\hline Village chief & $\begin{array}{l}\text { Good policy for increasing } \\
\text { income of local people }\end{array}$ & $\begin{array}{l}\text { We do not know how the } \\
\text { policy will be excercised }\end{array}$ \\
\hline Customary chief & Good policy for local people & We have not heard it \\
\hline Villagers & Good policy & $\begin{array}{l}\text { We have not got } \\
\text { information about the } \\
\text { policy }\end{array}$ \\
\hline
\end{tabular}

Source: Interview with some respondents ranging from policy makers, villagers, village chief and customary chief.

For respondents both at provincial, district and local level, the arrangement of village forest policy must avoid complicated and bureaucratic regulations. The key points for fostering the system are:

1. A clear distribution of right and responsibility between the main stakeholders;

2. Clear conflict resolution mechanisms;

3. A clear legal framework, especially village regulation with incentive and punishment mechanisms;

4. Equal and clear distribution of benefit;

5. Systemic capacity building;

6. Critical facilitation;

7. Political support from supra structure;

8. Efficient and extensive networking; and

9. Clear checks and balances mechanism for the village governance system. 
In legal point of view, the Law No. 32/2004 concerning decentralisation has supported the village forest policy. Article 206 of Law No 32/2004 stated that governance mechanisms that become prerogative of the village are: a) governance matters that had already existed in coincidence at the time of the birth of the village; b) governance matters that were under the authority of the district but are delegated to the rural level; c) assistance matters relevant to the provincial or district level; d) other governance matters that refer to the law are delegated to rural governance.

We consider that village forest policy would be very suitable to be designated in the area. There are some arguments beyond the bio-physical situation that make the decision appear rational and practicable:

1. The law and regulations that govern and rule the customary people have not made yet clearly;

2. There are many district regulations (Perda) that support the establishment of village forests;

3. Institutionally, the village forest policy still creates the possibility for the customary institutions to be the main actors in forest management; and

4. There is political support from the district government and other related stakeholders.

We consider that village forest policy would be better than customary forest designation for the Sepakat and Lantang Tallang village because the legal basis of operation would be stronger (P. No. 49/Menhut-II/200849) and it has also received political support verbally from related stakeholders such as some members of the House of Representative, and Local NGOs. Politically, the village forest approval process is quicker process than that for a customary village. ${ }^{48}$ It means the inauguration of the village forest does not need research done by a team as in the case of the customary. The inauguration also does not need a policy evaluation from other institutions, such as the Ministry of Internal Affairs.

In addition, the application of the village forest policy does not mean customary communities will lose their role. Under the village forest program, customary institutions could be the main players in the village forest governance system. It means that even though village forest would be an authority of village government, but village government could provide a more space for customary institution involved actively in managing forest, so the execution of the village forest would more legitimate.

\section{Conclusion}

The existence of multiple Perdas and orders that coexist in the Luwu Utara District, to some extent have give possibility to support the establishment of village forest in the area, especially in the Sepakat and Lantang Tallang village. The village forest could be managed by customary institution that endorsed by the chief of village.

In addition, the village forest may be better than customary forest for the Sepakat and LantangTallang village due to in legal aspect it will be stronger. Politically, the village forest needs quicker process than customary village. It has been supported from related stakeholder. The stipulation of the village forest does not mean customary communities will be losing their role. By the village forest, the customary institution could play as the main player in the village

${ }^{48}$ See appendix 4 
forest governance system.

One principle in making a formal legal framework is aimed to enable village forest can develop as the local people needs. The legal framework is made in the context to provide an incentive for the local people. The arrangement of village forest must avoid complicated and bureaucratic regulations.

\section{Bibliography}

\section{Books}

Von Benda Beckman, F., Keebet von Benda Beckman, Anne Grifiths. 2005. Mobile people, mobile law: Expanding legal relations in a contracting world. Ashgate Publishing.

Zen. Patraz. M., \& Mahyuni. R. 2007. Legal empowerment of the poor: lessons learned from Indonesia.YLBHI. Jakarta.

Eko, S, \&Rozaki, A. (2005). Prakarsa Desentralisasi dan Otonomi Desa. IRE PRESS: Jogjakarta

Vanschooten,H.,\&Vershuuren,J.2008.Introductionand conclusions (unformatted and unedited preprint version) from the book: International Governance and Law: State Regulation and Non-State Law. Edited book. Edward Elgar Publishing, Cheltenham. Tilburg University, the Netherlands

\section{Journal, Article, or Dissertation}

Li, T. M. 1999. Articulating indigenous identity in Indonesia resource politics and the tribal slot. Working Papers 007.Berkeley Workshop on Environmental Politics. Institute of international studies, university of california, berkeley

Li, T.M. "Articulating Indigenous Identity in Indonesia: Resource Politics and the Triba", Comparative Studies in Society and History, Vol. 42, No. 1 (January 2000)Cambridge University Press. pp. 149-179.

Li, T. M. 2001. "Masyarakat Adat, Difference, and the Limits of Recognition in Indonesia's Forest Zone" Modern Asian Studies 35(2001)Cambridge University Press. pp. 645-676.

Wibowo, L.R. "Village Forest: Conflicting knowledge systems and practices of development in Luwu Utara, Indonesia" International Journal of Social Forestry.

Susilaningtias. "Potret Hukum Adat Pada Masa Kolonia", Forum Keadilan No. 23. (01 Oktober 2006)

Sembiring, S. "Aspek Hukum Desa dan Hutan Desa: Sebuah tulisan Pembuka," SIKLUS Februari 2003.

Santosa, H. "Welcome: Village Forest?" (Warta Tenure 5 April 2008)

Peluso, N."Seeing property in land use: Localterritorializations in West Kalimantan, Indonesia", Danish Journal of Geography (2005): 105 (1): 1-15

Roth, D, "Ambition, Regulation and Reality: Complex use of land and water resources in Luwu, South Sulawesi, Indonesia,"(Dissertation of Wageningen University. The Netherlands,2003). 
Potter, Lesley. 2008. Dayak Resistance to Oil palm Plantations in West Kalimantan, Indonesia.This paper was presented to the 17th Biennial Conference of the Asian Studies Association of Australia in Melbourne 1-3 July 2008.

Langton, Marcia., Ma Rhea, Zane., Palmer, Lisa. Community-Oriented Protected Areas for Indigenous Peoples and Local Communities. Political Ecology Vol. 12 (2005)

Mac Andrews, C. "Transmigration in Indonesia: Prospects and Problems" Asian Survey: University of California, Vol. 18, No. 5 (May, 1978), pp. 458-472.

Bachriadi, D., \& Sardjono, M. A.(2006). Local Initiatives to Return Communities Control over Forest Lands in Indonesia: Conversion or Occupation? This paper had been prepared for 11th Biennial Conference of International Association for the Study of Common Property, Bali - Indonesia, June 1923, 2006.

Colchester, Marcus.(2000). "Indigenous Peoples and Biodiversity Conservation; Sector Review for the Biodiversity Support Program: Global Overview and South and South East Asia Review." Unpublished paper.

Colchester, Marcus. "Unity and Diversity: Indonesian policy towards tribal peoples," The Ecologist,16no.2/3 (1986): 89-98.

Colchester, Marcus. (2004). Conservation policy and Indigenous peoples. Environmental Science and Policy, 7 (2004): 145-153.

Fauzi, Noer. "Konsentrasi Kekayaan Atau Reforma Agrari?" Forum Keadilan(01 Oktober2006)

Hendra. Gunawan. "Implementasi Desentralisasi Salah Masyarakat Adat Menuai Masalah", (CIFOR. Bogor. Indonesia, 2005)

Moniaga, Sandra. "Pluralisme Hukum Negara dan Ketidakpastian Hak Masyarakat Adat" Forum Keadilan. (01 Oktober 2006)

Jatmiko, WA., H. de Foresta and A. Kusworo. 2000. Ketika Kebun Berupa Hutan: Agroforest Khas Indonesia Sebuah Sumbangan Masyarakat. ICRAF. Bogor.

Ngakan, P.O., Ahmad, A., Wiliam, D., Lahae, K., \& Tako, A. "The Dynamics of Decentralization in the Forestry Sector in South Sulawesi: The History, Realities and Challenges of Decentralized Governance", (Research of Hasanudin University and CIFOR Bogor. Indonesia, 2005)

Ngakan, P,O., Komarudin, H., Ahmad, A., Wahyudi, \& Tako, A. "Ketergantungan, Persepsi dan Partisipasi Masyarakat Terhadap Sumberdaya Hayati Hutan: Studi kasus di Dusun Pampli Kabupaten Luwu Utara, Sulawesi Selatan", (Reasearch of CIFOR. Bogor. Indonesia, 2006)

Safitri, Myrna. 2006. Change without Reform? Community Forestry in Decentralizing Indonesia.Paper presented at the 11th IASCP Conference, Bali 19-23 June 2006.

Hoey, Brian. A. "Nationalism in Indonesia: Building Imagined and International Communities through Transmigration" Ethnology Vol. 42. No.2.USA. (pp.109-26)

Yasmi,Y., Anshari, G.Z., Alqadrie,S., Budiarto, T., Ngusmanto, A, E., Komarudin, H., McGrath, S., Zulkifli, A. 2005. The Complexities of Managing Forest Resources in Post-decentralisation Indonesia: A case Study from Sintang District, West Kalimantan", (Research of CIFOR, 2005) 
Wibowo, L.R, Moeliono, M., Komarudin, H., Woro, C. M.R., Ismatul, H., Bangsawan,I. "Akses masyarakat terhadap sumberdaya hutan melalui pola pengelolaan hutan desa", (Research of CIFOR, 2007)

\section{Legal Documents}

PERDES.2006. Village Regulation No. 03 Tahun 2006 about Village Budgeting Planning (Anggaran Pendapatan dan Pengeluaran Keuangan Desa (APPKD). Lantang Tallang Kecamatan Masamba. Kabupaten Luwu Utara.

Perda . 2006. District Regulation No. 6 /2007 ebout village concensus board (BPD). Kabupaten Luwu Utara

Perda . 2007. District Regulation No. 07 Tahun 2007 about village governance system. Kabupaten Luwu Utara

Perda . 2007. District Regulation No. 09 Tahun 2007 about village budgetting. Kabupaten Luwu Utara

Perda . 2007. District Regulation No. 10 Tahun 2007 about village collaboration orpartnership. Kabupaten Luwu Utara

Perda . 2007. District Regulation No. 11 /2007 about the community institution. Kabuapetn Luwu Utara

Perda .2007. District Regulation No. 12 Tahun 2007 about village regulation. Kabupaten Luwu Utara

Perda .2007. District Regulation No 13 tahun 2007 about the delegation of the District authority to village. Kabupaten Luwu Utara

Perda .2007. District Regulation No. 14/2007 about the formation and changing legal status of the village. Kabupaten Luwu Utara

Perda. 2007. District Regulation No. 15/2007 about village development planning. Kabupaten Luwu Utara

The Ministry of Forestry and Statistical Bureau, 2007. Identification of villages in the foreststated land. Dephut in collaboration with BPS. Jakarta.

The Ministry of Forestry. 2008. The Ministry of Forestry Decision P.49/MenhutII/2008 about village forest. Jakarta.

The Basic Forestry Law. 1999. The Basic Forestry Law No. 41/1999 about forestry. Jakarta

The Basic Land Law. 1960. The Basic Land Law No. 5 tahun 1960. Jakarta.

\section{Websites}

Stable URL: http://www.jstor.org/stable/2643460 Accessed: 22/04/2009 03:01

Stable URL: http://www.jstor.org/stable/2696637 Accessed: 23/10/2008 22:48

\section{Other Sources}

Statistical Office. 2002. The Statistical Office of the Luwu Utara District. Kabupaten Luwu Utara. 
Empowerment Office. 2007. The list of Underdeveloped villages in Luwu Utara District. Kabupaten Luwu Utara.

AMAN. (2007). Laporan Hasil Kelompok IV Komunitas Masyarakat Adat Masapi Kabupaten Luwu Utara Provinsi Sulawesi Selatan.

Empowerment Office. 2007. The list of Underdeveloped villages in Luwu Utara District. Kabupaten Luwu Utara.

Forestry and estate crop service Luwu Utara District. (2001). "24 Permit Proposals in Forestry Areas and Areas for Other Purposes (APL) that need to convert forestry function in Luwu Utara". Kabupaten Luwu Utara

Forestry Service South Sulawesi Province. 2005. "Data and Information year 2005, Bajiminasa”. Makasar. Sulawesi Selatan

Hardiyanto, G. "Down to earth of village forest", Special EditionFebruari 2003

Monografi Desa Latang Tallang. Kecamatan Masamba, Kabupaten Luwu Utara. Sulawesi Selatan

Sepakat Village. 2001. Profile of Sepakat Village, Kecamatan Masamba, KabupatenLuwu Utara. Sulawesi Selatan

Meinzen-Dick, R. S., \& Pradahan, R.2002. Legal Pluralism and Dynamic Property Rights. CAPRi WORKING PAPER NO. 22 CGIAR Systemwide Program on Collective Action and Property Rights. International Food Policy Research Institute 2033 K Street, N.W. Washington, D.C. 20006 U.S.A..

\section{Appendices}

Table 1 A various Perdasthat linked with the Village

\begin{tabular}{|c|c|l|l|}
\hline No. & PERDA & \multicolumn{1}{|c|}{ Content } \\
\hline 1. & No. $6 / 2007$ & The village Consensus Board (BPD) \\
\hline 2. & No. $7 / 2007$ & The management of village governance. \\
\hline 3. & No. $9 / 2007$ & The village Budgeting \\
\hline 4. & No. $10 / 2007$ & The Village collaboration \\
\hline 5. & No. $11 / 2007$ & The community institution \\
\hline 6. & No. $12 / 2007$ & The Village Rule \\
\hline 7. & No. $13 / 2007$ & The delegation of the District authority to the village level \\
\hline 8. & No. $14 / 2007$ & $\begin{array}{l}\text { The establishment and changing of the legal status of the } \\
\text { village. }\end{array}$ \\
\hline 9. & No. 15/2007 & The village development planning \\
\hline
\end{tabular}

Source: the village autonomy, the Luwu Utara District 
Tabel 2 various village assets in the form of forest

\begin{tabular}{|c|l|l|}
\hline No. & \multicolumn{1}{|c|}{ District } & \multicolumn{1}{|c|}{ Terminology } \\
\hline 1. & The Agam District at Sumatera Barat Province & Forest Ulayat Nagari \\
\hline 2. & The Lampung Barat District, Lampung Province & Pekon Forest \\
\hline 3. & The Kutai Barat District, Kalimantan Timur Province & Kampung forest \\
\hline 4. & The Maros District, Sulawesi Selatan Province & Village Forest \\
\hline
\end{tabular}

Source:: A number of Perda in the post the Law No. 22/1999 about the regional government in Sembiring, (2003)

Tabel 3 the role of village forest economically

\begin{tabular}{|c|c|c|c|}
\hline $\begin{array}{c}\text { Village Forest } \\
\text { or with other } \\
\text { names }\end{array}$ & Site & $\begin{array}{l}\text { Income per capita } \\
\text { (Rp) or percentage of } \\
\text { its contribution to the } \\
\text { family income }\end{array}$ & $\begin{array}{c}\text { Source of } \\
\text { Information }\end{array}$ \\
\hline Repong Damar & $\begin{array}{l}\text { Krui, } \\
\text { Lampung }\end{array}$ & $70 \%$ till $100 \%$ & $\begin{array}{l}\text { Jatmiko et al. } \\
(2000)\end{array}$ \\
\hline Tembawang & $\begin{array}{l}\text { Kalimantan } \\
\text { Barat }\end{array}$ & $190.000-5.300 .000$ & $\begin{array}{l}\text { ICRAF } 2000 \\
\text { Jatmiko et al. } \\
(2000)\end{array}$ \\
\hline $\begin{array}{l}\text { Production forest } \\
\text { and formerly } \\
\text { managed by PT } \\
\text { Panply but now } \\
\text { the customary } \\
\text { people claims the } \\
\text { area }\end{array}$ & $\begin{array}{l}\text { Sepakat and } \\
\text { Lantang } \\
\text { Tallang } \\
\text { Village, } \\
\text { Luwu Utara }\end{array}$ & $\begin{array}{l}\text { the total of income } \\
\text { from rattan is about } \\
R p .110,000,000 \text { or } \$ \text { US } \\
12,222.22 \text { monthly and } \\
\text { this amount not include } \\
\text { the income from wood } \\
\text { based products }\end{array}$ & $\begin{array}{l}\text { Ngakan et al., } \\
\text { 2005; Wibowo, } \\
\text { forth coming }\end{array}$ \\
\hline
\end{tabular}

Table 4 Different process between customary forest and village forest

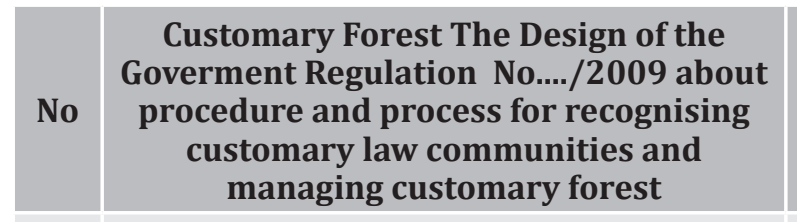

1. 1) Proposal the stipulation customary can be proposed by Bupati/Municipality or guvernor in accrodance with their authority after stipulated by the district regulation about the recognition of customary law communities.

\section{Village Forest P. No. 49/ Menhut-II/200849 Procedur for the stipulation of village forest working area}

Bupati or Municipality propose the appointment of village forest working area to the MoF on behalf of the chief of village enclose witha map and forest status or condition 
2) The proposal that conveyed by Governor to the MoF with cc to the Ministry of internal affair (in article 1).

3) The proposal as mentioned in article (2) and (3) attached by:

- Thedistrictregulation or theprovincial regulation about the recognition of customary law communities.

- The documents of reseach result on the existence of customary law communities and technical study of bio phisical of the proposed area.

2. 1) The ministry of internal affair, refers to the attacment of the proposal of custmary forest as mentioned in passage 12 article MoF.

2) The consideration as mentioned in article (1) informed to the MoF at least 30 days since the proposal letter arrived from governor. (topography, potency and forest function and The proposal should be cc to governor. (2) or (3), can give consideration to the

1) The MoF then verified by a team formed by the MoF

2) Director General of Forest Rehabilitation and Social Forestry as coordinator of verification assign technical implementation unit to do field verification and work in collaboration with the district government

3) The result of verification then reported to the team of verification as consideration (target of verification are legality of the area and forest function)

Towards the accepted proposal, then the team of verification will give information to Bupati or Municipality with cc to Governor

2) The assesment as mentioned in article (1) covers:

a. The research result of the existence of customary law communities;

b. The technical study of the proposed area.

4. 1) Towards the accepted proposal as mentioned in article (1) the MoF stipulates or recognised customary forest.

2) The recognition of customary law communities as mentioned in article (3) enclosed:

- Location, size and boundaries

- Right and responsibilities

- Rule of prohibitions and

- Evaluation 
Table 5 The list of village authorities in estate crops and forestry sectors

\begin{tabular}{|c|l|l|}
\hline No & \multicolumn{1}{|c|}{ Department } & \multicolumn{1}{c|}{ Remarks } \\
\hline 1. & $\begin{array}{l}\text { Water and soil } \\
\text { conservation }\end{array}$ & $\begin{array}{l}\text {-Management and village forest conservation } \\
\text {-Re-greening and soil conservation }\end{array}$ \\
\hline 2. & $\begin{array}{l}\text { Protection and } \\
\text { monitoring forest } \\
\text { product trade }\end{array}$ & $\begin{array}{l}\text {-Preventing and reporting forest degradation and forest } \\
\text { product trade } \\
\text {-Preventing, mitigating and reporting land and forest } \\
\text { fire }\end{array}$ \\
\hline 3. & $\begin{array}{l}\text { Utilisation of } \\
\text { natural resource }\end{array}$ & $\begin{array}{l}\text {-Monitoring over utilisation and people wood trade } \\
\text {-Utilisation and forest product management }\end{array}$ \\
\hline 4. & $\begin{array}{l}\text { Biodiversity } \\
\text { conservation }\end{array}$ & $\begin{array}{l}\text {-Preventing and reporting over protected wild animal } \\
\text { hunting } \\
\text {-Preventing and reporting over exploitation of protected } \\
\text { floras }\end{array}$ \\
\hline 5. & Pest control & $\begin{array}{l}\text {-Observation and arrangement of integrated estate crop } \\
\text { pest control on } \\
\text {-Monitoring over the development and expansion of } \\
\text { estate commodities in the area } \\
\text {-Observation the trade of illegal seedlings and } \\
\text { agricultural inputs }\end{array}$ \\
\hline
\end{tabular}

Table 6 the role relationship within village forest development

\begin{tabular}{|c|c|c|c|c|}
\hline Village & District & Central Government & Universities & NGOs \\
\hline $\begin{array}{l}\text { Management } \\
\text { Unit }\end{array}$ & Coordination & $\begin{array}{l}\text { Decide the status } \\
\text { and long-term } \\
\text { management plan }\end{array}$ & $\begin{array}{l}\text { Feasibility } \\
\text { study }\end{array}$ & Facilitator \\
\hline $\begin{array}{l}\text { Participatory } \\
\text { management } \\
\text { planning }\end{array}$ & $\begin{array}{l}\text { Technical } \\
\text { assistance and } \\
\text { management } \\
\text { plan }\end{array}$ & $\begin{array}{l}\text { Designated working } \\
\text { area }\end{array}$ & Facilitator & Advocacy \\
\hline $\begin{array}{l}\text { Institution } \\
\text { development }\end{array}$ & $\begin{array}{l}\text { Regulator, } \\
\text { facilitator and }\end{array}$ & $\begin{array}{l}\text { Regulator and } \\
\text { facilitator and } \\
\text { delivery mechanism }\end{array}$ & $\begin{array}{l}\text { Technical } \\
\text { consultant }\end{array}$ & $\begin{array}{l}\text { Capacity } \\
\text { building }\end{array}$ \\
\hline $\begin{array}{l}\text { Utilisation } \\
\text { and products } \\
\text { management }\end{array}$ & $\begin{array}{l}\text { Monitoring and } \\
\text { evaluation }\end{array}$ & $\begin{array}{l}\text { Making } \\
\text { implementation and } \\
\text { technical guidance }\end{array}$ & $\begin{array}{l}\text { Institutional } \\
\text { development }\end{array}$ & \\
\hline $\begin{array}{l}\text { Conflict } \\
\text { resolution }\end{array}$ & $\begin{array}{l}\text { Project support } \\
\text { (infrastructure } \\
\text { development) }\end{array}$ & $\begin{array}{l}\text { Monitoring and } \\
\text { evaluation }\end{array}$ & $\begin{array}{l}\text { Capacity } \\
\text { building }\end{array}$ & \\
\hline \multirow[t]{2}{*}{$\begin{array}{l}\text { Technical } \\
\text { planning }\end{array}$} & $\begin{array}{l}\text { Market } \\
\text { development }\end{array}$ & $\begin{array}{l}\text { Incentive mechanism } \\
\text { development }\end{array}$ & & \\
\hline & & $\begin{array}{l}\text { Market networking } \\
\text { and infrastructure } \\
\text { development }\end{array}$ & & \\
\hline
\end{tabular}

Source: Data analysed from primary data 